\title{
Detection of reassortant avian influenza A (H11N9) virus in environmental samples from live poultry markets in China
}

\author{
Ye Zhang ${ }^{1}$, Shu-Mei Zou', Xiao-Dan Li ${ }^{1}$, Li-Bo Dong ${ }^{1}$, Hong Bo ${ }^{1}$, Rong-Bao Gao ${ }^{1}$, Da-Yan Wang ${ }^{1}$
} and Yue-Long Shu ${ }^{1,2^{*}}$

\begin{abstract}
Background: Avian influenza viruses have caused human infection and posed the pandemic potential. Live poultry markets are considered as a source of human infection with avian influenza viruses. Avian influenza routine surveillance of live poultry markets is taken annually in China. We isolated the 2 H11 N9 influenza virus from the surveillance program. To better understand the risk caused by these new viruses, we characterize the genetic and pathogenicity of the two viruses.

Methods: Viral isolation was conducted with specific pathogen-free (SPF) embryonated chicken eggs. Whole genome was sequenced, and phylogenetic analysis was conducted.

Results: Two H11N9 viruses were identified, with all 8 segments belonging to the Eurasian lineage. The HA, NA, M, NS and PA genes were similar to virus isolates from ducks, and the NP, PB2 and PB1 gene segments were most similar to those viruses from wild birds, indicating that the H11N9 viruses might represent reassortant viruses from poultry and wild birds. The HA receptor binding preference was avian-like, and the cleavage site sequence of HA showed low pathogenic. The NA gene showed $94.6 \%$ identity with the novel H7N9 virus that emerged in 2013. There was no drug resistance mutation in the M2 protein. The Asn30Asp and Thr215Ala substitutions in the M1 protein implied a potentially increased pathogenicity in mice. Both viruses were low-pathogenic strains, as assessed by the standards of intravenous pathogenicity index (IVPI) tests.

Conclusion: Two reassortant H11N9 avian influenza viruses were detected. These viruses showed low pathogenicity to chickens in the IVPI test. Public health concern caused by the reassortant H11N9 viruses should be emphasized during the future surveillance.
\end{abstract}

Keywords: Avian influenza, H11N9, Genetic characterization, Reassortant

\section{Multilingual abstracts}

Please see Additional file 1 for translations of the abstract into the six official working languages of the United Nations

\section{Background}

Wild waterfowl are considered to be the natural reservoir of influenza A virus. There are currently 16 HA subtypes

\footnotetext{
* Correspondence: yshu@cnic.org.cn

${ }^{1}$ National Institute for Viral Disease Control and Prevention, Chinese Center for Disease Control and Prevention, Beijing 102206, China

${ }^{2}$ Key Laboratory for Medical Virology, National Health and Family Planning Commission, Beijing 102206, China
}

(H1-H16) and nine NA subtypes (N1-N9) circulating in birds [1], and the H17N10 and H18N11 subtypes have been detected in bats [2]. The 16 avian HA subtypes have been detected in North America and Europe; among them, H4, $\mathrm{H} 6$ and $\mathrm{H} 9$ are the most common subtypes, followed by $\mathrm{H} 3, \mathrm{H} 7, \mathrm{H} 11$ and $\mathrm{H} 5$ in birds and poultry $[3,4]$. By 2008, at least nine avian influenza HA subtypes and six NA subtypes had been reported in domestic ducks in eastern China [5].

Since 1900, H1, H2 and H3-subtype influenza A viruses have infected humans and have circulated within the human population. The first human infection with a highly pathogenic avian influenza H5N1 virus occurred in

\section{Biomed Central}

(c) 2016 The Author(s). Open Access This article is distributed under the terms of the Creative Commons Attribution 4.0 International License (http://creativecommons.org/licenses/by/4.0/), which permits unrestricted use, distribution, and reproduction in any medium, provided you give appropriate credit to the original author(s) and the source, provide a link to the Creative Commons license, and indicate if changes were made. The Creative Commons Public Domain Dedication waiver (http://creativecommons.org/publicdomain/zero/1.0/) applies to the data made available in this article, unless otherwise stated. 
Hong Kong in 1997 [6]. Subsequently, human infections with other subtypes, such as H9N2, H7N2 and H7N3, were occasionally reported. In 2013, human infection with novel influenza A (H7N9) virus was first identified in China [7]. Subsequently, the first human infections with an $\mathrm{H} 6 \mathrm{~N} 1$ virus and an $\mathrm{H} 10 \mathrm{~N} 8$ virus were reported in Taiwan and Jiangxi, China, respectively $[8,9]$.

Epidemiological investigation has shown that live poultry markets (LPMs) are important sources of human infection with avian influenza viruses [10]. Avian influenza viruses can be detected in poultry as well as in environmental samples from LPMs [11]. The contaminated environments may provide continual sources to the new coming batches of poultry.

Since 2009, we have undertaken a nationwide surveillance program to monitor avian influenza viruses in poultry-related environmental samples. In this study, we isolated two reassortant H11N9 viruses from an LPM in Jiangxi province during routine surveillance in 2009. Genetic and molecular evolutionary analyses indicate that they are low-pathogenic avian influenza viruses. To our knowledge, this is the first report to identify a reassortant avian H11N9 virus in environmental samples from an LPM.

\section{Methods}

\section{Sample collection}

Our nationwide routine avian influenza virus surveillance of environmental samples has been conducted in China since January 2009. The samples, including bird feces, drinking or contaminated water, and environmental swabs, were collected monthly from LPMs, slaughterhouses and farms. From January 2009 to December 2013, 33049 samples were collected from 142 cities in 31 provinces. The samples were placed into $15 \mathrm{~mL}$ tubes containing viral transport medium and sent to the laboratory for further testing. The viral transport medium consisted of $4 \mathrm{~mL}$ of minimum essential medium containing $0.5 \%$ BSA, $10 \%$ glycerol, $2 \times 10^{6} \mathrm{U} / \mathrm{L}$ penicillin G, $200 \mathrm{mg} / \mathrm{L}$ streptomycin, $2 \times 10^{6} \mathrm{U} / \mathrm{L}$ polymyxin $B$ sulfate, $250 \mathrm{mg} / \mathrm{L}$ gentamicin, $60 \mathrm{mg} / \mathrm{L}$ ofloxacin- $\mathrm{HCl}, 0.2 \mathrm{~g} / \mathrm{L}$ sulfamethoxazole and $5 \times 10^{5} \mathrm{U} / \mathrm{L}$ nystatin (Sigma, St. Louis, MO, USA).

\section{RNA extraction and real-time PCR}

An RNeasy Kit (Qiagen, Chatsworth, CA, USA) was used to extract viral RNA from the samples. Influenza A virus RNA was detected by real-time PCR (AgPath; Applied Biosystems, Foster City, CA, USA) targeting a matrix gene on a Stratagene Mx3005P thermocycler. The real-time RT-PCR amplification protocol included steps of $45^{\circ} \mathrm{C}$ for $10 \mathrm{~min}$ and $95{ }^{\circ} \mathrm{C}$ for $10 \mathrm{~min}$ and then 40 cycles of $95^{\circ} \mathrm{C}$ for $15 \mathrm{~s}$ and $60^{\circ} \mathrm{C}$ for $45 \mathrm{~s}$.

\section{Viral isolation}

Virus-positive samples were shipped to the Chinese National Influenza Center for viral isolation. The samples were inoculated into the allantoic cavities of 9-day-old embryonated chicken eggs that were then incubated at $37{ }^{\circ} \mathrm{C}$ for $48 \mathrm{~h}$ before being chilled at $4{ }^{\circ} \mathrm{C}$ overnight. The allantoic fluid was harvested, and virus identification was performed with a hemagglutination assay with $0.5 \%$ turkey red blood cells.

\section{Gene sequencing}

Eight gene segments of each virus were amplified with a One-Step RT-PCR kit (QIAGEN, Germany) according to the manufacturer's protocol. Complete genome amplification was performed using specific primers [12]. PCR products were purified with a QIAquick Gel Extraction Kit (QIAGEN, Germany) according to the manufacturer's protocol. Sequencing was performed using a BigDye Terminator v3.1 Cycle Sequencing Kit on an ABI PRISM 3700 xl DNA Analyzer (Applied Biosystems) according to the manufacturer's protocol.

\section{Phylogenetic analysis}

Sequences were assembled and edited with Lasergene 8.1 (DNASTAR). Neighbor-joining (NJ) trees were constructed using MEGA 5.0. The bootstrap value was tested with 1000 replications for each gene segment. Homology analyses of nucleic acids and amino acids were performed on the NCBI website with BLAST. All of the reference sequences used in the phylogenetic comparison were obtained from GenBank.

\section{IVPI test}

Fresh infective allantoic fluid with a HA titer $>16$ was diluted 1:10 in sterile isotonic saline. A sample $(0.1 \mathrm{ml})$ of the diluted virus was injected intravenously into each of 10 6-week-old SPF chickens. All of the chickens were examined daily for 10 days and scored based on the condition of each chicken: 0 (normal), 1 (sick), 2 (severely sick) and 3 (dead), as described in the OIE/WHO guidelines [13].

\section{Results \\ Molecular detection, viral isolation and subtype identification}

The proportion of influenza $M$ gene-positive environmental samples was $7.9 \%$, and the positive viral isolation rate was $1.5 \%$. The $\mathrm{H} 2, \mathrm{H} 3, \mathrm{H} 4, \mathrm{H} 5, \mathrm{H} 6, \mathrm{H} 7, \mathrm{H} 9$ and H11 subtypes were detected between year 2009 and 2013. Among all of the viral isolates, 2 H11N9 avian influenza viruses were separately isolated from two LPMs in Wuning city, Jiangxi province. Both viruses were isolated in 2009 and were named A/environment/Jiangxi/26/2009(H11N9) (JX/26/2009) and A/ 
environment/Jiangxi/28/2009(H11N9) (JX/28/2009). JX/ 26/2009 was collected from Xinning LPM on July 8, 2009, and JX/28/2009 was isolated from Guai LPM on July 8, 2009. The complete genome sequences of the influenza viruses have been deposited in GenBank under accession numbers KC881287 to KC881302.

\section{Homology comparison}

JX/26/2009 and JX/28/2009 were highly homologous, with greater than $99 \%$ identity in the nucleotide sequences of each segment. The lengths of the PB2, PB1, PA, HA, NA, NP, M and NS genes were 2341, 2341, 2233, 1754, 1453, 1565, 1027 and $890 \mathrm{bp}$, respectively. The HA gene showed the highest identity (99\%) with the Eurasian A/duck/ Chiba/11/2007(H11N9) virus, whereas the NA gene sequence showed 99 \% identity with the Eurasian A/duck/ Vietnam/G30/2008(H11N9) virus. The NA genes of the viruses were $94.6 \%$ identical to A/Anhui/1/2013(H7N9), the novel A(H7N9) virus identified in March 2013 in China. The nucleotide sequences of the internal genes showed high similarity with other avian influenza viruses from wild birds or ducks. The viruses in GenBank that had the highest amino-acid sequence homology to our newly identified viruses are shown in Table 1.

\section{Phylogenetic analysis}

The results of a phylogenetic analysis showed that the eight gene segments of the 2 H11N9 viruses isolated in this study all belonged to the Eurasian lineage, which was distinct from the branch of North American lineages in the tree (Fig. 1). The HA genes were closely related to A/ duck/Chiba/11/2007(H11N9), whereas their NA genes were in a separate subgroup from the $\mathrm{A}(\mathrm{H} 7 \mathrm{~N} 9)$ influenza virus.

The PB2, PB1, PA, NP, M and NS genes clustered with A/Velvet scoter/883 V/2009(H4N6), A/Mallard/Korea/ GH171/2007(H7N9), A/Duck/Jiangxi/25186/2009(H7N6), A/Wild duck/Korea/CSM20-5/2009(H4N6), A/Duck/ Jiangxi/26326/2010(H7N7) and A/Duck/Nanjing/1102/ 2010(H4N8), respectively.

\section{Molecular analysis}

The HA cleavage sites of the 2 H11N9 viruses were AIASR/G, which is characteristic of low-pathogenic avian influenza viruses. The Q226 residue of HA indicated that the receptor binding sites still recognize the $\alpha-2,3$ receptor (in $\mathrm{H} 3$ numbering). The mammalianadaptation mutations of PB2 $(627 \mathrm{~K}$ and $701 \mathrm{~N})$ were not found in either of the viruses, indicating that the viruses originated from an avian source.

The N30D and T215A substitutions in the M1 protein, which have been associated with increased $\mathrm{H} 5 \mathrm{~N} 1$ pathogenicity in mice [14], were found in JX/26/2009 and JX/ $28 / 2009$. No adamantine-resistance or neuraminidase drug-resistance mutations were detected in the M2 or NA proteins, respectively. The main amino acid mutations are shown in Table 2.

\section{IVPI test}

The IVPI scores were calculated according to the OIE/ WHO guidelines [13]. The IVPI scores of JX/26/2009 and JX/28/2009 were 0.43 and 0.6 , respectively, indicating that these $2 \mathrm{H} 11 \mathrm{~N} 9$ viruses are low-pathogenic avian influenza viruses.

\section{Discussion}

H11N9 has been reported in wild waterfowl in Brazil, Belgium, the Republic of Kazakhstan, and Japan [15-19]. This subtype virus has also been isolated from ducks in southern China and Hong Kong SAR [20].

From 2009 to 2013, two H11N9 avian influenza viruses were isolated during routine surveillance. The samples were collected from chicken cages in LPMs. Phylogenetic analyses indicated that all the gene segments belonged to the Eurasian lineage. The HA, NA and NP genes originated from H11N9 viruses, whereas the internal gene segments clustered with H7N7, H7N6 and H4N6. The Eurasian-lineage HA gene clusters with recently reported H11N9 viruses that have been found in wild birds or ducks (Fig. 1). H11N9 viruses have been identified as the donors of the NA gene of $\mathrm{H} 7 \mathrm{~N} 9$ virus

Table 1 Comparisons of A/Environment/Jiangxi/26/2009(H11N9) with Isolates in GenBank with highest nucleotide and amino acid identity

\begin{tabular}{llll}
\hline Gene segment & Virus with the highest nucleic acid homology & Percent homology (\%) & GenBank ID \\
\hline PB2 & A/velvet A/scoter/Mongolia/883 V/2009(H4N6) & 99 & KC986346.1 \\
PB1 & A/mallard/Korea/GH170/2007(H7N7) & 99 & FJ750870.1 \\
PA & A/duck/Jiangxi/25186/2009(H7N6) & 98 & KF260253.1 \\
HA & A/duck/Chiba/11/2007(H11N9) & 99 & AB669139.1 \\
NP & A/northern pintail/Hong Kong/MPC2085/2007(H11N9) & 98 & KF259789.1 \\
NA & A/duckNietnam/G30/2008(H11N9) & 99 & AB593465.1 \\
M & A/duck/Jiangxi/16326/2010(H7N7) & 99 & KF259249.1 \\
NS1 & A/duck/Nanjing/1102/2010(H4N6) & 99 & KC683707.1 \\
\hline
\end{tabular}




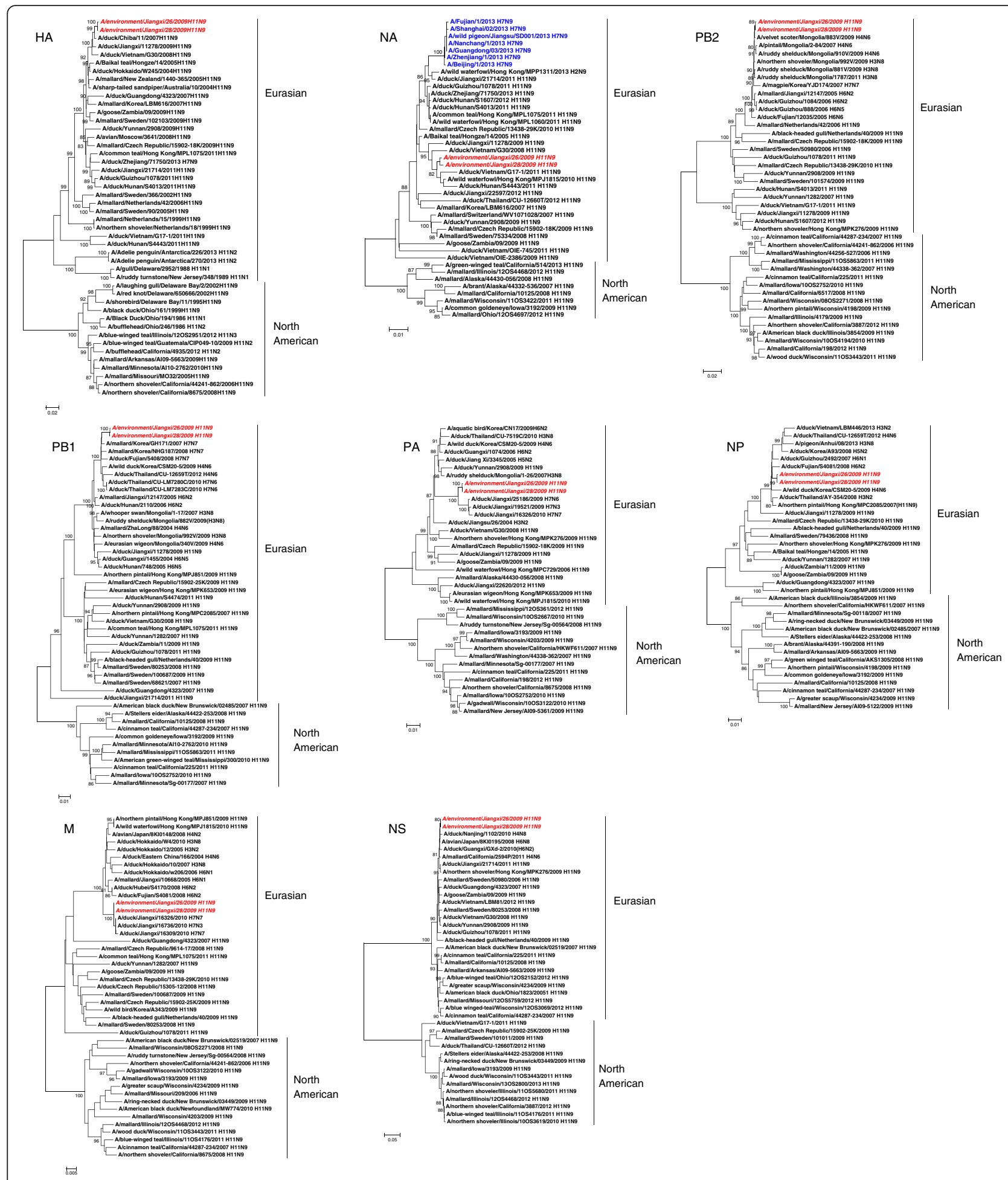

Fig. 1 Phylogenetic analysis of the A/Environment/Jiangxi/26/2009 and A/Environment/Jiangxi/28/2009 viruses. A/Environment/Jiangxi/26/2009 and A/Environment/Jiangxi/28/2009 are indicated by bold type. Numbers below nodes represent bootstrap values from 1000 replicates

in the 2013 [21]. The NA phylogenetic trees showed that the two H11N9 viruses in this study were in the Eurasian lineage together with NA of the H7N9 viruses, though they were in a separate subgroup from the
H7N9 viruses. The HA, NA, M and NS genes of the two strains of H11N9 viruses were derived from domestic ducks, whereas the polymerase and NP genes were derived from wild birds. It has been suggested that 
Table 2 Key amino acid residues analysis of A/environment/ Jiangxi/26/2009(H11N9) and A/environment/Jiangxi/28/ 2009(H11N9)

\begin{tabular}{llll}
\hline Protein & Mutation & Function & $\begin{array}{l}\text { JX/26/2009 and } \\
\text { JX/28/2009 }\end{array}$ \\
\hline HA & Q226L & $\begin{array}{l}\text { Receptor biding site. Q is the } \\
\text { avian signature. }\end{array}$ & Q \\
PB2 & E627K & $\begin{array}{l}\text { Enhances pathogenicity in mice } \\
\text { D701N }\end{array}$ & E \\
M1 & N30D & $\begin{array}{l}\text { increase the virulence of H5N1 } \\
\text { avian influenza viruses in mice }\end{array}$ & D \\
& T215A & A \\
M2 & S31N & resist to amantadine & S \\
& H274Y & & H \\
NA & E119V & resist to oseltamivir or zanamivir & E \\
& R152K & & R \\
\hline
\end{tabular}

shared water sources between waterfowl and poultry may enhance the possibility of reassortant avian influenza virus occurrence [22]. Indeed, the H11N9 viruses in our report were collected in water-rich areas in Jiangxi province. We hypothesize that the virus originated via the occasional reassortment of viral gene segments from wild birds, waterfowl and poultry. Recently, an H11N9 virus has been isolated from a domestic duck in LPMs in eastern China; this virus obtained its genes from $\mathrm{H} 11, \mathrm{H} 3, \mathrm{H} 10$ and $\mathrm{H} 7$ avian influenza viruses from ducks in Chinese LPMs [23]. Because LPMs provide favourable conditions for the reassortment of avian influenza viruses, this is important to strengthen the surveillance in LPMs to monitor the distribution and genetic variation of avian influenza viruses.

Among influenza A viruses, $\mathrm{H} 5$ and $\mathrm{H} 7$ are considered to be notable avian influenza viruses, but not all $\mathrm{H} 5$ and $\mathrm{H} 7$ viruses display high pathogenic. Low-pathogenic avian influenza viruses can be precursors of highly pathogenic viruses $[24,25]$. The two H11N9 viruses in this study are low-pathogenic avian influenza viruses. Their receptor binding sites retained an avian virus-like character. The N30D and T215A mutations observed in the M1 protein might increase the pathogenicity of these viruses in mice.

Reassortment among different influenza viruses is considered to be the main mechanism for the generation of new viruses, which may bear enhanced mammalian transmission and pandemic potential. It has been reported that $\mathrm{H} 11 \mathrm{~N} 9$ viruses can be transmitted directly to hunters from ducks [26]. New H11-subtype viruses have also been isolated from penguins [27]. Therefore, influenza virus subtypes other than the dominant $\mathrm{H} 5$, H7 and H9 subtypes should be emphasized. Continual monitoring is especially important for reassortant viruses, which may possess new characteristics that have implications for public health.

\section{Conclusion}

Two H11N9 influenza viruses were isolated from the live poultry markets in Jiangxi during the routine surveillance. All the segments of the viruses were belonging to the Eurasian lineage of influenza virus genes. The segments of the viruses are originated from both poultry and wild birds. The character of the genes origination highlights the important of Jiangxi province as the possible hot place of mixture the influenza viruses from both migratory wild birds and poultry. The NA genes of the two viruses are different from the novel H7N9 virus of 2013. The Both viruses were low-pathogenic strains from the IVPI tests and the molecular genes markers. The reassortant virus may possess new characteristics that may be of concern to public health, and continuous surveillance should be emphasized.

\section{Additional file}

Additional file 1: Multilingual abstracts in the six official working languages of the United Nations. (PDF $444 \mathrm{~kb}$ )

\section{Abbreviations}

IVPI, intravenous pathogenicity index; LPM, live poultry market; r RT-PCR, real-time reverse transcription-polymerase chain reaction; $R T-P C R$, reverse transcription-polymerase chain reaction; SPF, specific pathogen free

\section{Acknowledgements}

We thank the staff of the Jiangxi Provincial Influenza Surveillance Laboratory for assistance with collection of environmental-monitoring samples. We also thank the National Basic Research Grant (973) Plan for financially supporting this research.

\section{Authors' contributions}

YZ sequenced the whole genomes of the 2 strains of H11N9, performed sequence alignments and drafted the manuscript. Viral isolation was performed by SMZ. XDL and HB detected viral nucleic acids. LBD aligned all of the sequences. RBG designed and participated in the study. DYW and YLS designed the study and revised the manuscript. All of the authors approved the manuscript.

Competing interests

The authors declare that they have no competing interests.

\section{Grant information}

This research was supported by National Basic Research Grant (973) 2011CB504704.

Received: 9 November 2015 Accepted: 18 May 2016

Published online: 08 June 2016

\section{References}

1. Centers for Disease Control and Prevention. Types of Influenza Viruses. 2016 Available from: http://www.cdc.gov/flu/about/viruses/types.htm.

2. Tong S, Zhu X, Li Y, Shi M, Zhang J, Bourgeois M, et al. New World Bats Harbor Diverse Influenza A Viruses. PLoS Pathog. 2013:9(10):e100365.

3. Olsen B, Munster VJ, Wallensten A, Waldenström J, Osterhaus AD, Fouchier RA. Global patterns of influenza a virus in wild birds. Science. 2006;312(5772):384-8.

4. Munster VJ, Baas C, Lexmond P, Waldenstrom J, Wallensten A, et al. Spatial, Temporal, and Species Variationin Prevalence of Influenza A Viruses in Wild Migratory Birds. PLoS Pathog. 2007;3(5):e61.

5. Qiu B, Liu W, Peng D, Hu S, Liu X. Distribution of avian influenza virus subtypes among domestic ducks in eastern China. Acta Microbiologica Sinica. 2008;48(10):1290-4. 
6. Ungchusak K, Auewarakul P, Dowell SF, Kitphati R, Auwanit W, Puthavathana $\mathrm{P}$, et al. Probable person-to-person transmission of avian influenza A (H5N1). N Engl J Med. 2005;352:333-40.

7. Gao R, Cao B, Hu Y, Feng Z, Wang D, Hu W, et al. Severe Human Infections with a Novel Reassortant Avian-Origin Influenza A (H7N9) Virus. N Engl J Med. 2013;368(20):1888-97.

8. Shi W, Shi Y, Wu Y, Liu D, Gao GF. Origin and molecular characterization of the human-infecting H6N1 influenza virus in Taiwan. Protein Cell. 2013;4(11):846-53.

9. Chen H, Yuan H, Gao R, Zhang J, Wang D, Xiong Y, et al. Clinical and epidemiological characteristics of a fatal case of avian influenza A H10N8 virus infection : a descriptive study. Lancet. 2014;383(9918):714-21.

10. Wan XF, Dong L, Lan Y, Long LP, Xu C, Zou S, et al. Indications that Live Poultry Markets are a Major Source of Human H5N1 Influenza Virus Infection in China. J Virol. 2011:85:13432-8.

11. Jadhao SJ, Nguyen DC, Uyeki TM, Shaw M, Maines T, Rowe T, et al. Genetic analysis of avian influenza A viruses isolated from domestic waterfowl in live-bird markets of Hanoi, Vietnam, preceding fatal H5N1 human infections in 2004. Arch Virol. 2009;154:1249-61.

12. Hoffimann E, Stech J, Guan Y, Webster RG, Perez DR. Universal primer set for the full-length amplication of all influenza A viryses. Arch Virol. 2001; 146:2275-89.

13. OIE manual of diagnostic tests and vaccines for terrestrial animals 2016. http://www.oie.int/international-standard-setting/terrestrial-manual/accessonline/.

14. Shufang F, Guohua D, Jiasheng S, Guobin T, Yongbing S, Yongping J, et al. Two amino acid residues in the matrix protein $\mathrm{M} 1$ contribute to the virulence difference of H5N1 avian influenza viruses in mice. Virology. 2009; 384(1):28-32.

15. Van Borm S, Rosseel T, Vangeluwe D, Vandenbussche F, Van den Berg T, Lambrecht B. Phylogeographic analysis of avian influenza viruses isolated from Charadriiformes in Belgium confirms intercontinental reassortment in gulls. Arch Virol. 2012;157(8):1509-22.

16. Me Araujo J, De Azevedo Jr SM, Gaidet N, Hurtado RF, Walker D, Thomazelli LM, et al. Avian Influenza Virus (H11N9) in Migratory ShorebirdsWintering in the Amazon Region, Brazil. PLoS ONE. 2014;9(10):e110141.

17. Pawar S, Chakrabarti A, Cherian S, Pande S, Nanaware M, Raut S, et al. An avian influenza $A(H 11 N 1)$ virus from a wild aquatic bird revealing a unique Eurasian-American genetic reassortment. Virus Genes. 2010;41:14-22.

18. Jahangir A, Watanabe Y, Chinen O, Yamazaki S, Sakai K, Okamura M, et al. Surveillance of avian influenza viruses in Northern pintails (Anasacuta) in Tohoku District. Japan Avian Dis. 2008:52:49-53.

19. Karamendin K, Kydyrmanov A, Zhumatov K, Asanova S, Ishmukhametova N, Sayatov M. Phylogenetic analysis of avian influenza viruses of $\mathrm{H} 11$ subtypeisolated in Kazakhstan. Virus Genes. 2011;43(1):46-54.

20. Tan D, Huang JL, Wang CHJ, He SH, Wanag WG, Tang XM, et al. Genetic analysis and pathogenicity of $2 \mathrm{H} 11 \mathrm{~N} 9$ subtype avian influenza isolates from duck. Prog Vet Med. 2005;36(2):25-8.

21. Lam $T$, Wang J, Shen Y, Zhou B, Duan $L$, Cheung $C L$, et al. The genesis and source of the H7N9 influenza viruses causing human infections in China. Nature. 2013;502(7470):241-4.

22. Lang AS, Kelly A, Runstadler JA. Prevalence and diversity of avian.influenza viruses in environmental reservoirs. J Gen Virol. 2008:89:509-19.

23. Wu H, Peng $X$, Peng $X$, Nanping W. Molecular characterization of areassortant H11N9 subtype avian influenza virus isolated from a domestic duck in Eastern China. Arch Virol. 2015;160:2595-2601.

24. Alexander DJ. A review of avian influenza in different bird species. Vet Microbiol. 2000;74:3-13.

25. Alexander DJ. An overview of the epidemiology of avian influenza. Vaccine. 2007;25:5637-44

26. Gill JS, Webby R, Gilchrist MJ, Gray GC. Avian influenza among Waterfowl hunters and wildlife professionals. Emerg Infect Dis. 2006;12:1284-6.

27. Hurt AC, Vijaykrishna D, Butle J, et al. Detection of Evolutionarily Distinct Avian Influenza A Viruses in Antarctica. Mbio. 2014;5(3):e01098-14.

\section{Submit your next manuscript to BioMed Central and we will help you at every step:}

- We accept pre-submission inquiries

- Our selector tool helps you to find the most relevant journal

- We provide round the clock customer support

- Convenient online submission

- Thorough peer review

- Inclusion in PubMed and all major indexing services

- Maximum visibility for your research

Submit your manuscript at www.biomedcentral.com/submit
Biomed Central 